\title{
Storage studies of table wine produced from African bush mango (Irvingia gabonensis) and watermelon (Citrullus lanatus) blends
}

\author{
"Mbaeyi-Nwaoha, I.E. and Okorie, B. I. \\ Department of Food Science and Technology, University of Nigeria, Nsukka (www.unn.edu.ng) \\ *Corresponding author Email: miphie2003@yahoo.co.uk or ifeoma.mbaeyi-nwaoha@unn.edu.ng
}

\begin{abstract}
The work was carried out to study the storage characteristics of table wine formulated from blends of African bush mango (Irvingia gabonensis) and watermelon juice. The juices of watermelon (WM) and African bush mango (UG) were extracted, weighed, blended together in the ratios: 100: 0, 90: 10, 80: 20, 70: 30, 60: 40, 50: 50 and 0: 100 to each other and fermented with yeast to obtain watermelon-ugiri wine. The formulated table wine was subjected to sensory evaluation, physicochemical, microbial and proximate analyses for a period of four weeks. Sensory evaluation on the formulated table wine showed that sample UGWM2 (containing $100 \%$ watermelon) had the most acceptable mean score with 7.5 in week zero and 7.3 in week four for colour while sample UGWM7 (containing $50 \%$ African bush mango + $50 \%$ watermelon) was however rated lower than other samples for all sensory parameters both in week zero and week four. The highest total viable count was $8.9 \times 10^{5} \mathrm{cfu} / \mathrm{ml}$ in sample UGWM5 (containing 70 $\%$ watermelon $+30 \%$ African bush mango) for week zero while it reduced to $3.1 \times 10^{4} \mathrm{cfu} / \mathrm{ml}$ in week four. In the proximate composition, sample UGWM1 (containing $100 \%$ African bush mango) had the highest fat content with $4.65 \%$ in week zero and $3.95 \%$ in week four. The moisture content was found to be in the range of $90.91 \%$ in sample UGWM4 to $93.25 \%$ in sample UGWM2 in week zero and $91.19 \%$ UGWM4 (containing $80 \%$ watermelon + $20 \%$ African bush mango) to $93.29 \%$ UGWM2 in week four. The ash was in the range $0.15 \%$ in sample UGWM4 to $0.925 \%$ in sample UGWM2 in week zero while it ranged from $0.17 \%$ in sample UGWM4 to $0.93 \%$ in sample UGWM2 for week four. Low protein content was also observed in all the samples. Sample UGWM1 had the least carbohydrate in week zero with $\mathbf{1 . 3 2 5 \%}$ and to $2.23 \%$ in week four. Sample UGWM4 on the other hand had the highest carbohydrate content of $7.63 \%$ in week zero and $7.065 \%$ in week four. The alcohol volume ranged from 6.0 to $11.5 \%$ both in week zero and four. The sample UGWM1 has the least pH value of 1.93 both in week zero and four while sample UGWM5 had the highest with 2.405. The titratable acidity was in the range of 0.225 $\mathrm{mg} / \mathrm{ml}$ to $0.41 \mathrm{mg} / \mathrm{ml}$. The results of the four weeks showed that the $\mathrm{pH}$ and titratable acidity of the formulated table wine were relatively stable.
\end{abstract}

Key words: African bush mango (Irvingia gabonensis), Fermentation, Table wine, Watermelon (Citrullus lanatus), Storage

\section{INTRODUCTION}

Wine is an alcoholic beverage that is produced by the fermentation of sugars in fruit juices, most especially grape juice. Originally, the production was carried out with grapes; however, any other non-toxic plant material containing starch or sugar up to $30 \%$ can be used. The quality of the grape or other fruit that replaces it determines the quality of wine produced. Based on alcoholic content, wines are categorized into table wine (with alcoholic content of between 7 and 14 by volume) and dessert wines (with alcoholic content of between 14 and 24 by volume). Table wine is also divided into still table wine and sparkling table wine based on the carbon 
dioxide $\left(\mathrm{CO}_{2}\right)$ content. Still table wines are further divided into three groups: red, rosé (blush), and white, based on the color of the wine (USEPA, 1995).

The leading producers of wine in the world are the European Union (EU) with $40 \%$ of vines areas and $60 \%$ of wine production. The European Union is also the largest consumer of wine in the world (60\%) as well as the main actors in the international market (both as the top exporter and the top importer) with France, Italy and Spain together accounting for over $80 \%$ of wine production in Europe and the world (EC, 2006). Originally, wines are taken for pleasure but have also been discover to have functional properties especially the red wine.

Over the years, wines have been made exclusively from grapes-different species of grapes thereby giving only countries with climate favourable to the growth of grapes the exclusive right to produce, process and market wines. The climatic condition of Nigeria does not support the growth of grapes large enough for industrial usage so the need to substitute grapes with locally cultivated fruits. The production of wines from water melon and African bush mango (Irvingia gabonensis) blends, also reduce waste of these fruits as seen today thereby giving the farmer more value for their effort. Nigeria has also introduced some policies like the local content act and the transformation agenda of the agricultural sector with the aim of developing locally produced raw materials.

Also, it should be noted that for some years now, people have resolve into making their own beverages. Some are due to health challenges, others due to the need to monitor the process to give a particular taste, others for different other reasons. Most of these homemade beverages many times do not last for a long period of time so the need for storage of these beverages so they can last longer.

The large quantity of waste as seen in the agricultural sector today needs to be greatly reduced, this study intends to show other uses to these fruits- African bush mango (Irvingia gabonensis) and watermelon (Citrullus lanatus) so as to compensate for the farmers effort.

Watermelon (Citrullus lanatus) and African bush mango (Irvingia gabonensis) or ugiri as popularly called in Igbo have also been discovered to possess phytochemicals which in turn gives functionality to the wine. Watermelon seeds are a source of protein, B vitamins, minerals (such as magnesium, potassium, phosphorous, sodium, iron, zinc, manganese and copper) and fat among others (Collins et al., 2007; Vandermark, 2011; Anon, 2015a). The most important of these bioactive constituents (phytochemicals) of plants are steroids, terpenoids, carotenoids, flavanoids, alkaloids, tannins and glycosides. These phytochemicals are antibiotic principles of plants (Ajayi et al., 2011). Thus, consumption of a variety of plant foods including watermelon seeds may provide additional health benefits.
Antioxidants that retard the oxidation process may additionally exhibit antimicrobial activity.

Studies have shown that that moderate drinkers of alcoholic drinks (for instance, one glass for women and three glasses for men daily) have lower risk of cardiovascular disease than non-drinkers especially red wine drinkers because red wine contains resveratol which is a powerful antioxidant compound that protects internal organs like the heart and arteries from saturated fat.

The fruits are readily available as well as cheap to buy especially for African bush mango which can be gotten by obtaining permission to pick them on farms from farmers with a promise to return back the seeds.

The broad aim was to carry out storage studies of table wine from African bush mango or ugiri and water melon blends and specifically to evaluate the chemical, microbiological count and sensory properties of the formulated table wine blends during storage.

\section{MATERIALS AND METHODS}

\section{Procurement of raw materials}

Watermelon (Citrullus lanatus) was purchased from Ogige main market, Nsukka, Enugu State. African bush mango (Irvingia gabonensis) were obtained from Ajuona Obukpa, Nsukka while the sodium metabisulphate was obtained from Food Microbiology/Biotechnology laboratory, Department of Food Science and Technology, University of Nigeria, Nsukka.

\section{Sample preparation}

\section{Processing of watermelon juice}

The watermelon juice was processed after thorough sorting and washing. The watermelon ball was then sliced into smaller pieces. The small pieces of watermelon were then passed through a juice extractor to obtain the juice. The juice was sieved to remove the seed and the fibre component of the juice. The quantity of watermelon juice used was $2250 \mathrm{ml}$. The diagram is represented below in Figure 1.

\section{Processing of African bush mango pulp into juice}

The African bush mangoes were sorted, washed, peeled, sliced into two equal halves to remove the seed or kernel and chopped into smaller pieces. The smaller pieces were blended together with the addition of water to obtain ugiri juice. The juice was then sieved to remove the fibrous component and a clear must was obtained. The flow diagram is given below in Figure 2 . 

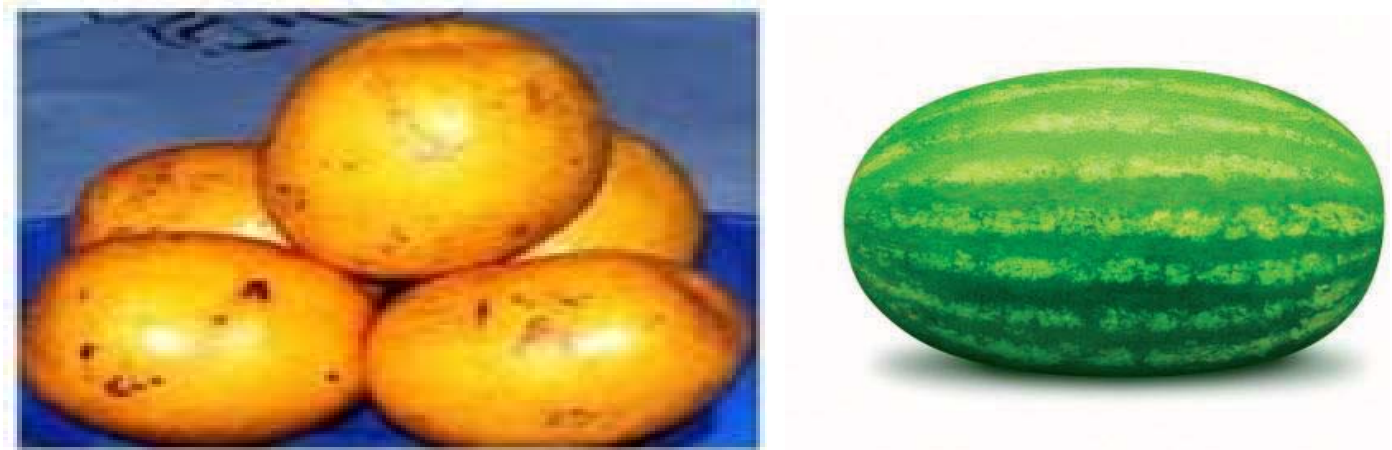

Plate 1: Picture of African bush mango fruits

Plate 2: Watermelon ball

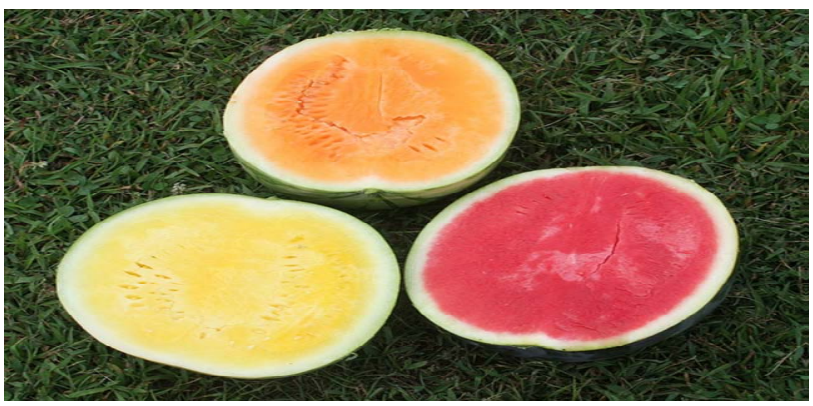

Plate 3: Halfed watermelon balls of different varieties

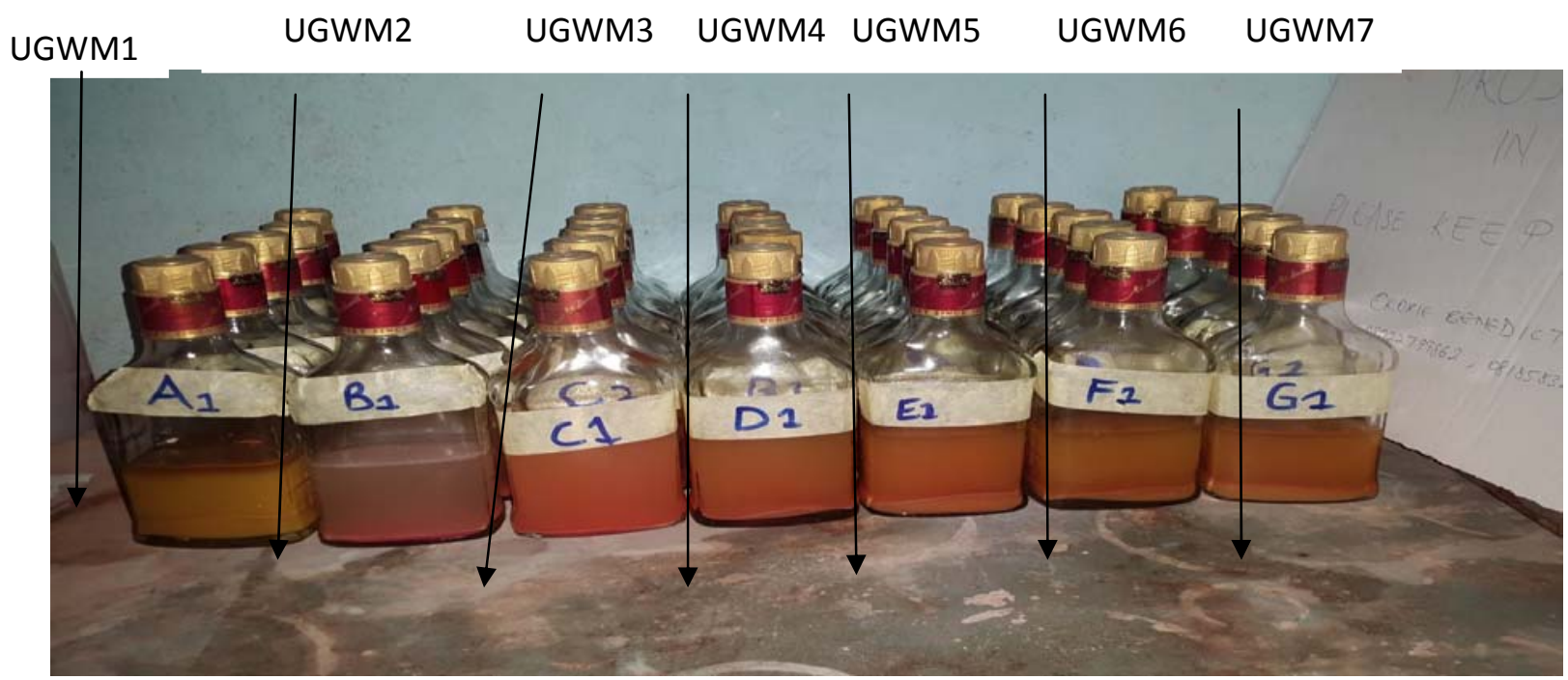

Plate 4. Picture of formulated table wine from ugiri and watermelon blends

Key: UGWM1 = 100\% Ugiri; UGWM2 = 100\% Watermelon; UGWM3 = 90\% watermelon + 10\% ugiri; UGWM4 = 80\% watermelon + 20\% ugiri; UGWM5 = 70\% watermelon + 30\% ugiri; UGWM6 = 60\% watermelon + 40\% ugiri; UGWM7 = $50 \%$ watermelon $+50 \%$ ugiri; NB: UG $=$ African bush mango or ugiri; $\mathrm{WM}=$ watermelon

The watermelon and African bush mango must were then weighed out according to the blends in Table 1. Each blend total of $500 \mathrm{ml}$ into a different bottle of $750 \mathrm{ml}$ capacity, after which the starter culture that was prepared a day before was added to each bottle. The starter culture was prepared by adding $1 \mathrm{~g}$ of Brewer's yeast powder (Saccharomyces cerevisae) into $100 \mathrm{ml}(50 \mathrm{ml}$ of watermelon $+50 \mathrm{ml}$ of African bush mango) of the must, after which $15 \mathrm{ml}$ of the solution was added to $500 \mathrm{ml}$ of the formulated watermelon + African bush mango juice as shown in Figure 3.

The watermelon and African bush mango must were then weighed out according to the blends to fermentation (primary) was allowed to take place for one week but sodium metabisulphite was added after 24 hours of fermentation. 
016 Afr. J. Food Sci. Technol.

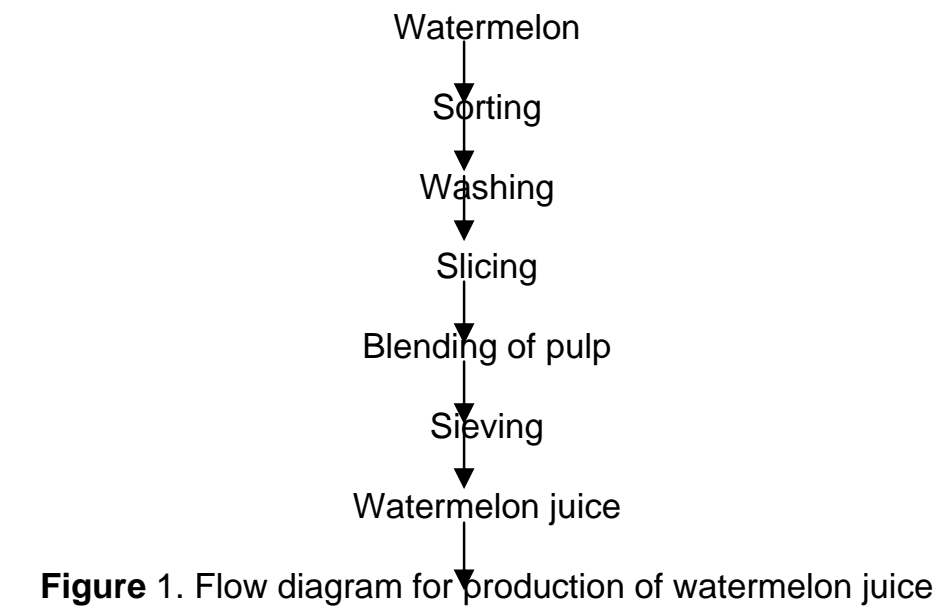

Figure 1. Flow diagram for production of watermelon juice

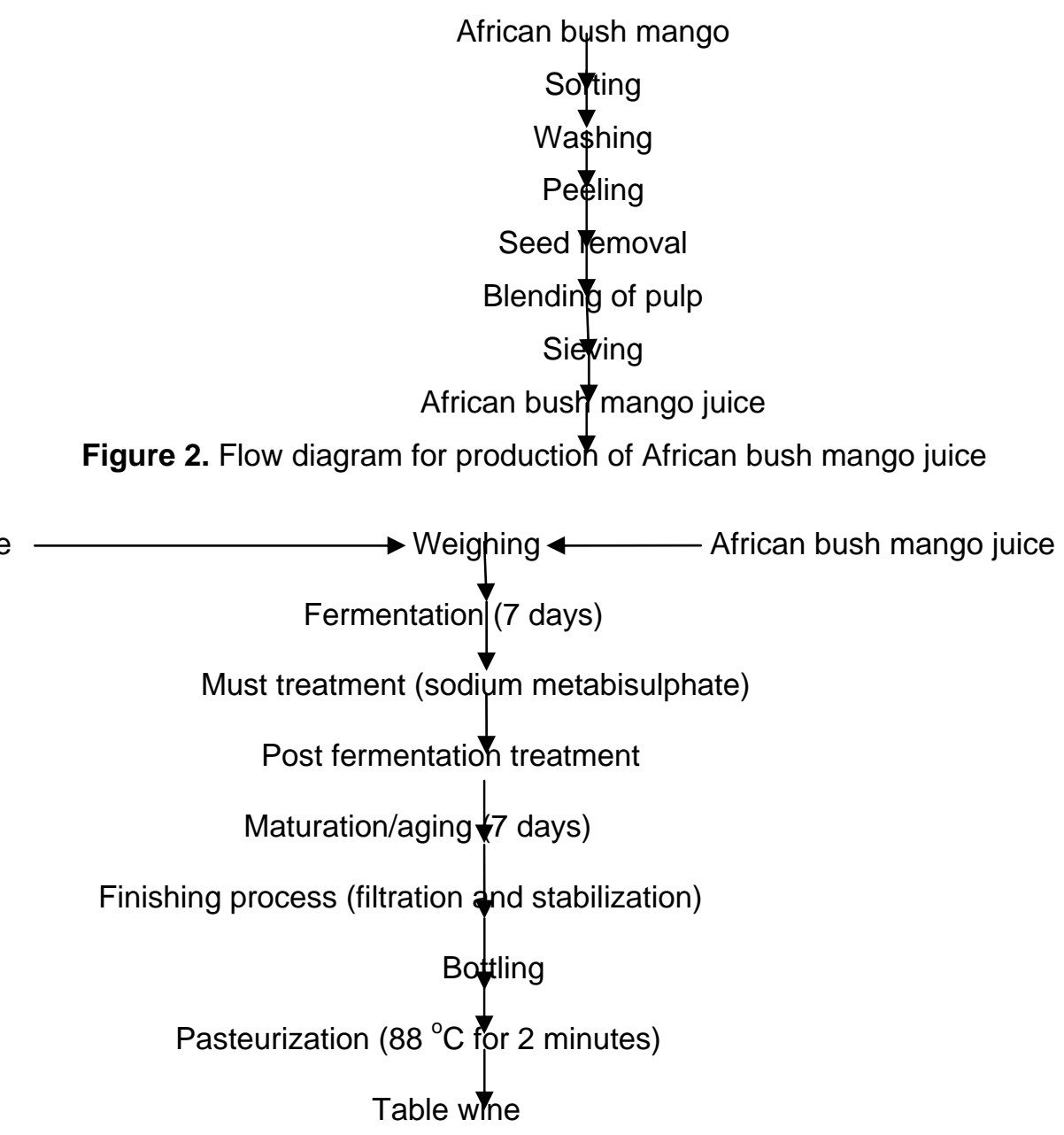

Watermelon juice Mixing

Figure 3. Flow diagram for production of ugiri and watermelon blends

Then, $0.063 \mathrm{~g}$ of sodium metabisulphite was used in each $500 \mathrm{ml}$ of the formulated watermelon + African bush mango must. During maturation/aging, the wine was first filtered so as to remove the excess yeast growth to pave way for a slower secondary fermentation where the desired sharp taste was formed as well as mouthfeel, aroma and taste would be improved upon (Wang, 2015). The proportions of blends of the formulated must are given in Table 1.
Sample Analyses

Proximate analysis of the formulated table wine from African bush mango and watermelon blends

\section{Determination of moisture content}

Moisture was determined using the hot air oven method described in AOAC (2010). Two millilitres (2ml) of the 
Table 1. Proportion of the formulated must for table wine production from watermelon and African bush mango blends

\begin{tabular}{lcc}
\hline Sample & Watermelon (\%) & African bush mango (\%) \\
\hline UGWM1 & 100 & 0 \\
UGWM2 & 0 & 100 \\
UGWM3 & 90 & 10 \\
UGWM4 & 80 & 20 \\
UGWM5 & 70 & 30 \\
UGWM6 & 60 & 40 \\
UGWM7 & 50 & 50 \\
\hline
\end{tabular}

Key: UGWM1 = 100\% Ugiri; UGWM2 = 100\% Watermelon; UGWM3 = 90\% watermelon + 10\% ugiri; UGWM4 = 80\% watermelon + $20 \%$ ugiri; UGWM5 = 70\% watermelon $+30 \%$ ugiri; UGWM6 $=60 \%$ watermelon $+40 \%$ ugiri; UGWM7 $=50 \%$ watermelon $+50 \%$ ugiri.

NB: UG = African bush mango or ugiri; $W M=$ watermelon

sample was transferred into the moisture dish and dried for $2-3$ hours at $100-105{ }^{\circ} \mathrm{C}$. The sample was cooled by placing in desiccators before weighing again to obtain the final weight after drying. The percentage moisture content was calculated as:

Moisture content $(\%)=\frac{W_{3}-W_{1}}{W_{2}-W_{1}} \times \frac{100}{1}$

Where; $W_{1}=$ weight of sample in grams, $W_{2}=$ weight of crucible + sample before drying, $W_{3}=$ weight of crucible and sample after drying.

\section{Determination of ash content}

The ash content was determined using the method described by AOAC (2010). Two millilitres $(2 \mathrm{ml})$ of the sample was transferred into a weight porcelain dish, and dried at $100{ }^{\circ} \mathrm{C}$ for $3-4$ hours in a mechanized convection air oven (Phoenix furnace, model 534, SN: 524-85, Chapel town, Shefffield). The dish was removed and placed in a muffle furnace for ignition at $550{ }^{\circ} \mathrm{C}$ for 12 -18 hours to remove carbon after drying in the oven. The muffle furnace was turned off and allowed to cool to 250 ${ }^{0} \mathrm{C}$ to avoid losing the fluffy ash. The percentage ash content of each sample was then calculated as:

Ash content $(\%)=\frac{W_{3}-W_{1}}{W_{2}} \times \frac{100}{1}$

Where; $\mathrm{W}_{1}=$ weight of empty crucible, $\mathrm{W}_{2}=$ weight of sample, $W_{3}=$ weight of ashed + crucible

\section{Determination of crude protein of the formulated table wine.}

The crude protein content was determined using the method described by AOAC (2010), where a Soxhlet apparatus reflux condenser and $500 \mathrm{ml}$ round bottom flask was fixed. Then, $2 \mathrm{ml}$ of each of the sample was put into different filter papers and folded. Crude protein for each was determined by putting one of the folded filter papers containing one sample into a Kjeldahl round bottom flask. After which, $20 \mathrm{ml}$ of concentrated tetraoxosulphate $(\mathrm{VI})$ acid and 2 tablets of Kjeldahl catalyst were added. The apparatus was assembled and the solution was digested until the solution was clear. It was distilled by adding $200 \mathrm{ml}$ of water and $50 \mathrm{ml}$ of a 45 $\%$ of sodium hydroxide $(\mathrm{NaOH})$ and sodium thiosulphate to avoid loss of ammonia in the process. Afterwards, 60 $\mathrm{ml}$ of boric acid and 3 drops of methyl red were then added to a $100 \mathrm{ml}$ conical flask and placed at the receiver end. The apparatus was set until it got to the $100 \mathrm{ml}$ point inside the conical flask. The solution was titrated with $0.1 \mathrm{M}$ sodium hydroxide $(\mathrm{NaOH})$ and the titre value was recorded and calculated as:

Protein content $(\%)=0.001410 \times 6.25 \times 25 \times \mathrm{T}$

$5 \mathrm{~W}$

Where; $\mathrm{W}=$ weight of sample; $6.25=$ protein conversion factor for wine; $T=$ titre value

\section{Determination of crude fat}

The fat content was determined by AOAC (2010) using Soxhlet extraction method. A sample of $300 \mathrm{ml}$ petroleum esther was poured into a round bottom flask and the Soxhlet apparatus was setup at a temperature of $50{ }^{\circ} \mathrm{C}$. Then, $2 \mathrm{ml}$ of the sample was placed in labelled thimble. The extractor was sealed with cotton wool. Heat was applied to reflux the apparatus for six hours. The thimble was removed with care. The petroleum was recovered for reuse. When the flask was free of ether, it was removed and dried at $105{ }^{\circ} \mathrm{C}$ for 1 hour in an oven. The flask was cooled in a desiccator and weighed.

Calculation: $\%$ fat $=\frac{\text { Weight of fat }}{\text { Weight of sample }} \quad \frac{100}{1}$

\section{Determination of carbohydrate content}

The percentage of carbohydrate was carried out by difference as described by AOAC (2010). 
Carbohydrate content $(\%)=100-(\%$ protein $+\%$ fat $+\%$ ash $+\%$ crude fibre $+\%$ moisture) .

Physiochemical analyses of the formulated table wine from African bush mango and watermelon blends

\section{Determination of $\mathrm{pH}$}

The $\mathrm{pH}$ was measured using the potentiometric method as described by AOAC (2010). Five millilitres $(5 \mathrm{ml})$ of the sample was pipetted into a beaker and the $\mathrm{pH}$ was determined by dipping the electrodes into the sample and reading off the value on the screen of the meter.

\section{Determination of titratable acidity $(\mathrm{mg} / \mathrm{ml})$}

The method described by AOAC (2010) was used to determine titratable acid. Then, five millilitres $(5 \mathrm{ml})$ of the sample was taken and titrated with $0.1 \mathrm{~N}$ alkali $(\mathrm{NaOH})$ using $0.5 \mathrm{ml}$ phenolphthalein as indicator. Titration continued until there was change in colour to a pink end point. Titration was repeated to get an average result.

Titratable acidity $=\mathrm{M}(\mathrm{NaOH}) \times 0.09 \times 100$

$$
\text { Volume of sample }
$$

\section{Determination of alcoholic content}

The alcoholic content of the formulated wine was determined using AOAC (2010). A $100 \mathrm{ml}$ of each sample was measured in a volumetric flask at $20{ }^{\circ} \mathrm{C}$ and washed into a distillation flask with $50 \mathrm{ml}$ water. The acidity was neutralized with $0.1 \mathrm{~N}$ - sodium hydroxide and distilled slowly into the same $100 \mathrm{ml}$ flask. About $90 \mathrm{ml}$ of each sample was collected and made up to $100 \mathrm{ml}$ with water at $20{ }^{\circ} \mathrm{C}$ while the specific gravity was determined at 20 ${ }^{\circ} \mathrm{C}$ using specific gravity bottle (pyconometre). The alcoholic content was estimated as percentage by volume using standard curve.

Determination of some selected micronutrient of the formulated table wine from African bush mango and watermelon blends

\section{Determination of calcium content}

According to AOAC (2010), $2 \mathrm{ml}$ of the sample was diluted with $3 \mathrm{ml}$ distilled water and $1 \mathrm{ml}$ of $50 \%$ ammonium oxalate. One drop of methyl red indicator was made alkaline with ammonium drops of glacial acetic acid until colour changes to pink. This was stood for 4 hours and centrifuged for 5 minutes, followed by decantation of the supernatant. Then, $1 \mathrm{ml}$ of hydrogen sulphate was added to the residues which were diluted with $4 \mathrm{ml}$ of distilled water. The solution was boiled with $0.02 \mathrm{~N}$ potassium permanganate.

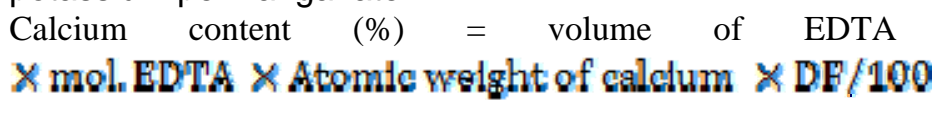

Weight of sample $\times 10$

Where; DF = Dilution factor

\section{Determination of phosphorus content}

Phosphorus content was determined using AOAC (2010), $5 \mathrm{ml}$ of the sample was pipetted into $50 \mathrm{ml}$ graduated flask with $10 \mathrm{ml}$ of molybdate mixture was added and diluted with water to mark point on the graduated flask. It stood for 15 minutes for colour development. The absorbance at $400 \mathrm{~mm}$ against blank was measured. The $\mathrm{ppm}$ or $\mathrm{mg} / \mathrm{ml}$ from the graph was calculated well as the number of $\mathrm{mg}$ of equivalent to the absorbance of the sample and blank determination.

\section{Determination of the vitamin A content}

Vitamin A was carried out using Kirk and Sawyer (1991), $1 \mathrm{ml}$ of the sample was pipetted in triplicate into a glass stopped test tube, and added to $1 \mathrm{ml}$ of petroleum ether. It was heated in a water bath to dryness. After drying 0.2 $\mathrm{ml}$ of the chloroform acetic anhydride was added, followed by $2 \mathrm{ml}$ of tetra citric acid chloroform was added immediately and absorbance taken at $620 \mathrm{~nm}$ using spectrophotometer.

\section{Determination of vitamin C (ascorbic acid)}

Vitamin C was determined as described by AOAC (2010), $1 \mathrm{ml}$ of the sample was titrated with $20 \mathrm{ml}$ of $0.4 \%$ oxalate acid. Also, $9 \mathrm{ml}$ of indophenols reagent was read from spectrophotometer in order to determine the absorbance of $520 \mathrm{~nm}$ against a blank.

\section{Microbial analyses of the formulated table wine from ugiri and watermelon blends}

\section{Determination of total viable count}

According to Prescott et al. (2005), $26 \mathrm{~g}$ of nutrient agar was dissolved in $500 \mathrm{ml}$ of distilled water was sterilized. The sample and sterilized quarter strength of ringer solution were used. After which, $1 \mathrm{ml}$ of the sample and 9 $\mathrm{ml}$ ringer solution was made for serial dilutions. The 
Table 2. Proximate composition of formulated table wine blends for week zero

\begin{tabular}{llllll}
\hline Sample & Moisture & Fat & Ash & Protein & Carbohydrate \\
\hline UGWM1 & $93.16^{\mathrm{a}} \pm 1.46$ & $4.65^{\mathrm{d}} \pm 0.58$ & $0.475^{\mathrm{bc}} \pm 0.08$ & $0.23^{\mathrm{b}} \pm 0.03$ & $1.325^{\mathrm{a}} \pm 0.13$ \\
UGWM2 & $93.25^{\mathrm{a}} \pm 0.35$ & $1.05^{\mathrm{ab}} \pm 0.08$ & $0.925^{\mathrm{d}} \pm 0.13$ & $0.075^{\mathrm{a}} \pm 0.01$ & $3.88^{\mathrm{b}} \pm 0.38$ \\
UGWM3 & $92.92^{\mathrm{a}} \pm 4.68$ & $1.1^{\mathrm{ab}} \pm 0.37$ & $0.59^{\mathrm{c}} \pm 0.01$ & $0.11^{\mathrm{ab}} \pm 0.01$ & $5.28^{\mathrm{c}} \pm 0.42$ \\
UGWM4 & $90.91^{\mathrm{a}} \pm 3.39$ & $1.25^{\mathrm{bc}} \pm 0.16$ & $0.15^{\mathrm{a}} \pm 0.01$ & $0.065^{\mathrm{a}} \pm 0.01$ & $7.63^{\mathrm{d}} \pm 0.89$ \\
UGWM5 & $92.51^{\mathrm{a}} \pm 0.68$ & $1.55^{\mathrm{bc}} \pm 0.13$ & $0.28^{\mathrm{ab}} \pm 0.10$ & $0.05^{\mathrm{a}} \pm 0.01$ & $5.615^{\mathrm{c}} \pm 0.26$ \\
UGWM6 & $92.69^{\mathrm{a}} \pm 3.2$ & $0.92^{\mathrm{a}} \pm 0.16$ & $0.44^{\mathrm{d}} \pm 0.11$ & $0.40^{\mathrm{c}} \pm 0.14$ & $5.573^{\mathrm{c}} \pm 0.77$ \\
UGWM7 & $93.15^{\mathrm{a}} \pm 1.89$ & $1.89^{\mathrm{c}} \pm 0.17$ & $0.485^{\mathrm{bc}} \pm 0.08$ & $0.6^{\mathrm{a}} \pm 0.01$ & $3.8789^{\mathrm{b}} \pm 0.63$
\end{tabular}

Values are in means \pm standard deviation of duplicate determination. Values with the same superscript in the same column are not significantly $(p<0.05)$ different.

Key: UGWM1 = 100\% Ugiri; UGWM2 = 100\% Watermelon; UGWM3 = 90\% watermelon $+10 \%$ ugiri; UGWM4 $=80 \%$ watermelon + $20 \%$ ugiri; UGWM5 $=70 \%$ watermelon $+30 \%$ ugiri; UGWM6 $=60 \%$ watermelon $+40 \%$ ugiri; UGWM7 $=50 \%$ watermelon $+50 \%$ ugiri . NB: UG = African bush mango or ugiri; WM = watermelon

diluted solution was pipetted into a marked Petri dish, swirled to mix and incubated at $37{ }^{\circ} \mathrm{C}$ for 24 hours. After incubation, the number of colonies was counted and represented as colony forming unit per millilitre.

\section{Determination mould count}

According to Prescott et al. (2005), Sabourand dextrose agar (SDA) was prepared with $32.5 \mathrm{~g}$ of the media and diluted in $500 \mathrm{ml}$ of distilled water. The SDA media solution $(15-20 \mathrm{ml})$ was added to the $1 \mathrm{ml}$ of the sample in the petri dish. It was properly mixed and allowed to set before incubating at $37^{\circ} \mathrm{C}$ for 48 hours. After incubation, the number of colonies were counted and represented as colony forming unit per millilitre.

\section{Sensory evaluation of formulated table wine from ugiri and watermelon blends}

Sensory properties of the samples were evaluated using 20 semi-trained panellists consisting of students of the University of Nigeria, Nsukka for various sensory attributes (flavour, colour, aroma, taste, after-taste, mouthfeel and overall acceptability). The degree of acceptance/preferences among the formulated table wines samples for each sensory quality was measured on a nine-point Hedonic scale; where "9" represent extremely like and "1" represemts extremely dislike (Iwe, 2002).

\section{Data analyses and experimental design}

The experiment was laid on a Completely Randomized Design (CRD). The mean and standard deviation were calculated by one-way analysis of variance using a computer software-Statistical package for social sciences, SPSS version 16 . Means were separated by Duncan's new multiple range test. Significance was accepted at $p<0.05$ according to Steel and Torrie (1980).

\section{RESULTS AND DISCUSSION}

\section{Proximate composition of the formulated table wine from African bush mango and watermelon blends}

The proximate composition of the formulated table wine blends is shown in Table 2 for week zero and Table 3 for week four. The moisture content of sample UGWM4 (containing $80 \%$ watermelon $+20 \%$ African bush mango) was the least in week zero with $90.92 \%$ moisture while sample UGWM2 (containing $100 \%$ watermelon) had the highest moisture content of $93.25 \%$ in that same week. The high moisture content of the formulated table wine can be attributed to the high moisture content of watermelon and ugiri especially because their must principally were used in the production of the table wine.

The mean values for moisture content of the blends in week zero were similar to the result $(94.6 \%, 94.63 \%$, $94.65 \%, 94.68 \%, 94.71 \%$ and $94.99 \%$ obtained from watermelon and pawpaw wine) reported by Adedeji and Oluwalana (2013).

The fat content of sample UGWM1 in week zero however, stood out with $4.65 \%$ and had the highest significant $(p<0.05)$ difference. This may probably be due to the high fat content of ugiri as reported by Ogunsina et al. (2012). Other blends of the formulated table wine also show a fat content within the range of $0.92 \%$ in sample UGWM6 and $1.89 \%$ in sample UGWM7 which had the second highest fat content. 
Table 3. Proximate composition of formulated table wine after week four

\begin{tabular}{llllll}
\hline Sample & Moisture & Fat & Ash & Protein & Carbohydrate \\
\hline UGWM1 & $93.03^{\mathrm{a}} \pm 1.43$ & $3.95^{\mathrm{b}} \pm 0.35$ & $0.57^{\mathrm{c}} \pm 0.16$ & $0.23^{\mathrm{b}} \pm 0.14$ & $2.23^{\mathrm{a}} \pm 0.14$ \\
UGWM2 & $93.29^{\mathrm{a}} \pm 1.40$ & $1.7^{\mathrm{a}} \pm 1.41$ & $0.93^{\mathrm{d}} \pm 0.01$ & $0.09^{\mathrm{a}} \pm 0.14$ & $4.005^{\mathrm{ab}} \pm 1.12$ \\
UGWM3 & $92.93^{\mathrm{a}} \pm 1.95$ & $1.4^{\mathrm{a}} \pm 0.28$ & $0.34^{\mathrm{ab}} \pm 0.13$ & $0.09^{\mathrm{a}} \pm 0.00$ & $5.415^{\mathrm{cd}} \pm 1.46$ \\
UGWM4 & $91.19^{\mathrm{a}} \pm 1.40$ & $1.5^{\mathrm{a}} \pm 0.71$ & $0.17^{\mathrm{a}} \pm 0.06$ & $0.07^{\mathrm{a}} \pm 0.14$ & $7.065^{\mathrm{e}} \pm 1.36$ \\
UGWM5 & $92.6^{\mathrm{a}} \pm 1.27$ & $1.25^{\mathrm{a}} \pm 0.35$ & $0.205^{\mathrm{a}} \pm 0.21$ & $0.055^{\mathrm{a}} \pm 0.01$ & $5.89^{\mathrm{a}} \pm 0.62$ \\
UGWM6 & $92.68^{\mathrm{a}} \pm 1.39$ & $1.3^{\mathrm{a}} \pm 0.14$ & $0.465^{\mathrm{bc}} \pm 0.11$ & $0.505^{\mathrm{a}} \pm 0.01$ & $5.05^{\mathrm{ca}} \pm 0.69$ \\
UGWM7 & $93.21^{\mathrm{a}} \pm 1.35$ & $2.25^{\mathrm{ab}} \pm 1.91$ & $0.26^{\mathrm{ab}} \pm 0.01$ & $0.665^{\mathrm{c}} \pm 0.78$ & $3.61^{\mathrm{ab}} \pm 0.69$ \\
\hline
\end{tabular}

Values are in means \pm standard deviation of duplicate determination. Values with the same superscript in the same column are not significantly $(p<0.05)$ different.

Key: UGWM1 = 100\% Ugiri; UGWM2 = 100\% Watermelon; UGWM3 = 90\% watermelon + 10\% ugiri; UGWM4 = 80\% watermelon + $20 \%$ ugiri; UGWM5 $=70 \%$ watermelon $+30 \%$ ugiri; UGWM6 $=60 \%$ watermelon $+40 \%$ ugiri; UGWM7 $=50 \%$ watermelon $+50 \%$ ugiri. NB: UG = African bush mango or ugiri; $\mathrm{WM}=$ watermelon

The ash content of the formulated table wine ranged from $0.15 \%$ in sample UGWM4 to $0.925 \%$ in sample UGWM2. As with fruits and vegetables, the protein content of the formulated table wine blends were very low with sample UGWM5 (containing $70 \%$ watermelon +30 $\%$ African bush mango) having the least protein mean value of the formulated table wine for week zero while sample UGWM7 had the highest with $0.665 \%$. The ash and crude protein content of all the blends in week zero were similar to result $(0.3 \%$ and $0.70 \%$ obtained from pawpaw and banana wine) reported by Awe et al. (2013) for ash content and the result $(0.021 \%$ in fresh tomato wine and $0.024 \%$ in 6 month aged tomato wine) reported by Many et al. (2014) for crude protein content. The sample UGWM1, however had the least carbohydrate mean value with $2.23 \%$ and sample UGWM4 having the highest significant $(p<0.05)$ difference in week zero.

Table 3 showed the proximate composition of the formulated table wine in the fourth week, the proximate composition could be stated to be relatively the same as there was no significant $(p<0.05)$ difference between the values obtained in week zero and those obtained in week four. The moisture content of the formulated table wine had a mean moisture within the range of $91.19 \%$ and $93.29 \%$ with sample UGWM2 still having the highest moisture content and sample UGWM4, the lowest just as in week zero. The values obtained were also similar to those reported by Adedeji and Oluwalana (2013) for moisture content. Sample UGWM1 had the highest fat content with $3.95 \%$ while sample UGWM5 (containing 70 $\%$ watermelon $+30 \%$ African bush mango) had the least fat content with $1.25 \%$ and sample UGWM6 having 1.3 $\%$. Sample was observed not to be significantly $(p<0.05)$ different in week four just like in week zero while sample UGWM2 was not significantly $(p<0.05)$ different in week four just as in week zero. The mean ash content values of the formulated table wine blends were not different from the result $(0.3 \%$ and $0.70 \%$ obtained from pawpaw and banana wine) reported by Awe et al. (2013).

The protein also followed the same trend as seen in week zero with sample UGWM5 having the least significant mean value and sample UGWM7 having the highest mean value. The values were also found just as in week zero to be similar to the result reported by Awe et al. (2013) and Many et al. (2014). Week four, however, showed no deviate from week zero in the carbohydrate composition of the formulated table wine blends with sample UGWM1 had the lowest carbohydrate value at $2.23 \%$ and sample UGWM4 having the highest mean values at $7.065 \%$.

The proximate composition of the week zero (when the storage studies was initiated) was found not to be significantly $(p<0.05)$ different from the results obtained after week four (when the studies was terminated). There was, however few differences in the proximate composition of both weeks and this implied that the exact values were not obtained in week four but the values obtained were similar to the expected changes in the proximate composition of the formulated table wine as storage continued. It therefore showed that the proximate composition of the formulated table wine would remain relatively the same over a long period of time. It also showed that the fermentation had stopped and there was no further breakdown of soluble solids in the formulated table wine blends was observed.

\section{Physiochemical properties of table wine formulated from African bush mango and watermelon blends}

\section{$\mathrm{pH}$ of the formulated table wine}

The mean $\mathrm{pH}$ value for sample UGWM1 containing 100 $\%$ African bush mango (Irvingia gabonensis) for the zero 
Table 4. $\mathrm{pH}$ values of the formulated table wine blends for a four week period

\begin{tabular}{llllll}
\hline Sample & Week 0 & Week 1 & Week 2 & Week 3 & Week 4 \\
\hline UGWM1 & $1.97^{\mathrm{a}} \pm 0.01$ & $1.97^{\mathrm{a}} \pm 0.01$ & $1.975^{\mathrm{a}} \pm 0.01$ & $2.15^{\mathrm{a}} \pm 0.01$ & $1.93^{\mathrm{a}} \pm 0.01$ \\
UGWM2 & $2.315^{\mathrm{cd}} \pm 0.02$ & $2.38^{\mathrm{e}} \pm 0.01$ & $2.395^{\mathrm{c}} \pm 0.01$ & $2.425^{\mathrm{d}} \pm 0.01$ & $2.375^{\mathrm{de}} \pm 0.01$ \\
UGWM3 & $2.29^{\mathrm{c}} \pm 0.01$ & $2.27^{\mathrm{b}} \pm 0.01$ & $2.29^{\mathrm{b}} \pm 0.01$ & $2.42^{\mathrm{cd}} \pm 0.01$ & $2.265^{\mathrm{b}} \pm 0.01$ \\
UGWM4 & $2.25^{\mathrm{b}} \pm 0.01$ & $2.31^{\mathrm{c}} \pm 0.00$ & $2.305^{\mathrm{b}} \pm 0.01$ & $2.29^{\mathrm{b}} \pm 0.01$ & $2.295^{\mathrm{c}} \pm 0.01$ \\
UGWM5 & $2.365^{\mathrm{e}} \pm 0.01$ & $2.355^{\mathrm{d}} \pm 0.01$ & $2.43^{\mathrm{d}} \pm 0.01$ & $2.37^{\mathrm{cd}} \pm 0.01$ & $2.405^{\dagger} \pm 0.01$ \\
UGWM6 & $2.335^{\mathrm{de}} \pm 0.01$ & $2.365^{\mathrm{de}} \pm 0.01$ & $2.395^{\mathrm{c}} \pm 0.01$ & $2.355^{\mathrm{bc}} \pm 0.01$ & $2.39^{\mathrm{ef}} \pm 0.01$ \\
UGWM7 & $2.355^{\mathrm{e}} \pm 0.01$ & $2.365^{\mathrm{de}} \pm 0.01$ & $2.405^{\mathrm{c}} \pm 0.01$ & $2.337^{\mathrm{bc}} \pm 0.09$ & $2.365^{\mathrm{d}} \pm 0.01$ \\
\hline
\end{tabular}

Values are in means \pm standard deviation of duplicate determination. Values with the same superscript in the same column are not significantly $(\mathrm{p}<0.05)$ different.

Key: UGWM1 = 100\% Ugiri; UGWM2 = 100\% Watermelon; UGWM3 = 90\% watermelon $+10 \%$ ugiri; UGWM4 $=80 \%$ watermelon $+20 \%$ ugiri; UGWM5 $=70 \%$ watermelon $+30 \%$ ugiri; UGWM6 $=60 \%$ watermelon $+40 \%$ ugiri; UGWM7 $=50 \%$ watermelon + $50 \%$ ugiri. NB: UG = African bush mango or ugiri; WM = watermelon

Table 5. Alcohol content (\% alcohol beverage volume, ABV) of formulated table wine blends

\begin{tabular}{llllll}
\hline Sample & Week 0 & Week 1 & Week 2 & Week 3 & Week 4 \\
\hline UGWM1 & $6.0^{\mathrm{a}} \pm 1.41$ & $7.2^{\mathrm{a}} \pm 2.83$ & $7.0^{\mathrm{a}} \pm 1.41$ & $6.5^{\mathrm{a}} \pm 0.71$ & $6.0^{\mathrm{a}} \pm 1.41$ \\
UGWM2 & $10.1^{\mathrm{c}} \pm 2.80$ & $9.0^{\mathrm{ab}} \pm 4.24$ & $8.0^{\mathrm{c}} \pm 1.41$ & $8.0^{\mathrm{ab}} \pm 1.41$ & $8.5^{\mathrm{b}} \pm 0.71$ \\
UGWM3 & $8.3^{ \pm} \pm 2.80^{\mathrm{b}}$ & $8.5^{\mathrm{a}} \pm 0.00$ & $10.3^{\mathrm{abc}} \pm 1.41$ & $10.0^{\mathrm{a}} \pm 2.83$ & $9.5^{\mathrm{bc}} \pm 0.71$ \\
UGWM4 & $9.7^{\mathrm{ab}} \pm 0.01$ & $10.0^{\mathrm{b}} \pm 5.66$ & $10.1^{\mathrm{ab}} \pm 0.01$ & $9.5^{\mathrm{abc}} \pm 0.71$ & $9.5^{\mathrm{bc}} \pm 0.71$ \\
UGWM5 & $10.5^{\mathrm{c}} \pm 4.24$ & $10.5^{\mathrm{b}} \pm 0.71$ & $10.5^{\mathrm{a}} \pm 0.71$ & $10.5^{\mathrm{bc}} \pm 0.71$ & $11^{\mathrm{cd}} \pm 1.41$ \\
UGWM6 & $10.7^{\mathrm{b}} \pm 1.41$ & $11.0^{\mathrm{ab}} \pm 1.41$ & $11.5^{\mathrm{c}} \pm 0.71$ & $11.5^{\mathrm{c}} \pm 1.41$ & $11.5^{\mathrm{d}} \pm 0.71$ \\
UGWM7 & $10.9^{\mathrm{c}} \pm 1.41$ & $11.5^{\mathrm{c}} \pm 1.41$ & $11.9^{\mathrm{bc}} \pm 0.71$ & $11.5^{\mathrm{abc}} \pm 0.71$ & $11.5^{\mathrm{cd}} \pm 0.01$ \\
\hline
\end{tabular}

Values are in means \pm standard deviation of duplicate determination. Values with the same superscript in the same column are not significantly $(p<0.05)$ different. Key: UGWM1 $=100 \%$ Ugiri; UGWM2 $=100 \%$ Watermelon; UGWM3 $=90 \%$ watermelon $+10 \%$ ugiri; UGWM4 $=80 \%$ watermelon $+20 \%$ ugiri; UGWM5 $=70 \%$ watermelon $+30 \%$ ugiri; UGWM6 $=60 \%$ watermelon $+40 \%$ ugiri; UGWM7 $=50 \%$ watermelon $+50 \%$ ugiri. NB: UG $=$ African bush mango or ugiri; $\mathrm{WM}=$ watermelon

week was 1.97 while the mean $\mathrm{pH}$ value for the fourth week of the same sample was 1.93 .

The $\mathrm{pH}$ (Table 4) of each of the formulated table wine were not significantly $(p<0.05)$ throughout the four weeks storage studies. Also, sample UGWM1 had the lowest $\mathrm{pH}$ of all the formulated table wine throughout the period of the storage studies and this implies that it relatively more acidic than other blends. The mould and total viable counts also gave credence to the fact that microbial activities were retarded in UGWM1 than other blends. Sample UGWM5 (containing $70 \%$ watermelon + $30 \%$ African bush mango) had the highest $\mathrm{pH}$ mean value throughout the period of storage. The $\mathrm{pH}$ of the formulated table wine were also observed to be relatively the same throughout the period of the study. The importance of the low $\mathrm{pH}$ as seen in the product include: increase antimicrobial action of the $\mathrm{SO}_{2}$ in form of sodium metabisulphite, increase colour expression in wines, selection of desirable micro-organisms, enhanced clarification of juices and wines, enhanced expression of fruit character and promote balance of wine colour (McCarthy, 2013). The pH of the formulated table wine were also similar to the $\mathrm{pH}$ values: $3.10,3.0,2.80,2.60$, 2.40, 2.20, and 2.0 reported by Akubor (1996), Adedeji and Oluwalana (2013) from watermelon and pawpaw wine, though lower than the specified 3.4 minimum for table wine according to EC (2006).

\section{Alcohol content (ABV) of the formulated table wine}

Table 5 showed that sample UGWM1 had an alcohol content of $6.0 \% \mathrm{ABV}$ in the week zero, while sample UGWM7 had the highest alcohol content of $10.9 \%$ in 
022 Afr. J. Food Sci. Technol.

Table 6. Titratable acidity in $\mathrm{mg} / \mathrm{ml}$ of the formulated table wine

\begin{tabular}{llllll}
\hline Sample & Week 0 & Week 1 & Week 2 & Week 3 & Week 4 \\
\hline UGWM1 & $0.34^{\mathrm{c}} \pm 0.02$ & $0.41^{\mathrm{c}} \pm 0.01$ & $0.375^{\mathrm{e}} \pm 0.01$ & $0.41^{\mathrm{c}} \pm 0.14$ & $0.3^{\mathrm{d}} \pm 0.28$ \\
UGWM2 & $0.30^{\mathrm{b}} \pm 0.01$ & $0.30^{\mathrm{b}} \pm 0.00$ & $0.26^{\mathrm{b}} \pm 0.02$ & $0.34^{\mathrm{b}} \pm 0.4$ & $0.29^{\mathrm{a}} \pm 0.01$ \\
UGWM3 & $0.30^{\mathrm{b}} \pm 0.00$ & $0.30^{\mathrm{b}} \pm 0.0$ & $0.30^{\mathrm{c}} \pm 0.02$ & $0.30^{\mathrm{b}} \pm 0.14$ & $0.265^{\mathrm{c}} \pm 0.08$ \\
UGWM4 & $0.26^{\mathrm{a}} \pm 0.02$ & $0.26^{\mathrm{a}} \pm 0.02$ & $0.25^{\mathrm{b}} \pm 0.00$ & $0.34^{\mathrm{b}} \pm 0.06$ & $0.225^{\mathrm{ab}} \pm 0.04$ \\
UGWM5 & $0.30^{\mathrm{b}} \pm 0.04$ & $0.31^{\mathrm{b}} \pm 0.02$ & $0.34^{\mathrm{d}} \pm 0.14$ & $0.3^{\mathrm{b}} \pm 0.00$ & $0.26^{\mathrm{c}} \pm 0.02$ \\
UGWM6 & $0.30^{\mathrm{b}} \pm 0.00$ & $0.3^{\mathrm{b}} \pm 0.00$ & $0.26^{\mathrm{b}} \pm 0.02$ & $0.265^{\mathrm{a}} \pm 0.89$ & $0.225^{\mathrm{ab}} \pm 0.01$ \\
UGWM7 & $0.29^{\mathrm{b}} \pm 0.02$ & $0.33^{\mathrm{b}} \pm 0.01$ & $0.23^{\mathrm{a}} \pm 0.04$ & $0.26^{\mathrm{a}} \pm 0.02$ & $0.225^{\mathrm{ab}} \pm 0.02$ \\
\hline
\end{tabular}

Values are in means \pm standard deviation of duplicate determination. Values with the same superscript in the same column are not significantly $(p<0.05)$ different.

Key: UGWM1 = 100\% Ugiri; UGWM2 = 100\% Watermelon; UGWM3 = 90\% watermelon + 10\% ugiri; UGWM4 = 80\% watermelon + 20\% ugiri; UGWM5 = 70\% watermelon + 30\% ugiri; UGWM6 $=60 \%$ watermelon + 40\% ugiri; UGWM7 = 50\% watermelon + 50\% ugiri. NB: UG = African bush mango or ugiri; $\mathrm{WM}=$ watermelon

week zero. The alcohol content of the formulated table wine in week one ranged between $7.2 \%$ in sample UGWM1 and $12.0 \%$ in sample UGWM7 due to breakdown of more sugar moieties. The samples, however showed the same trend of week one, two and three with sample UGWM1 having the least percentage alcohol and sample UGWM7 having the highest. In week four, however, both samples UGWM6 and UGWM7 had the highest percentage alcohol of $11.5 \%$. This high alcohol content with low $\mathrm{pH}$ contributed to resistance of the formulated table wine blends to microbial proliferation. The high yield of alcohol is attributed to the breakdown of soluble solids in the must to alcohol. The alcohol content of the formulated table wine was found to be similar to the results $(1.3 \%, 2.1 \%, 3.3 \%, 4.5 \%, 5.8$ $\%, 6.1 \%, 6.9 \%, 7.5 \%, 8.1 \%$ and $9.6 \%)$ of the work done on Hibiscus sabdariffa Linn wine by Ifie et al. (2012) and Teniola et al. (2012). It also falls within the alcohol level of table wine (USEPA, 1995).

\section{Titratable acidity of the formulated table wine blends}

The titratable acidity of the formulated table wine from ugiri and watermelon blends in Table 6 showed that sample UGWM4 (containing $80 \%$ watermelon + $20 \%$ African bush mango) had the least titratable acidity throughout the four weeks period of storage and sample UGWM1 had the highest titratable acidity throughout the four weeks storage period. There was no significant $(p<$ 0.05 ) difference between the titratable acidity values of all the formulated table wine within the four weeks storage period. These data were similar to those $(0.2 \mathrm{~g} / \mathrm{l}$ and 0.4 $\mathrm{g} / \mathrm{l})$ reported by Awe (2011) on pawpaw wine and Idise (2011) coconut wine though lower than the stipulated range of $0.5 \mathrm{mg} / \mathrm{ml}$ (Anon 2015b) for table wine but higher than those reported by Teniola et al. (2012).

\section{Micronutrient composition of the formulated table wine blends}

Table 7 showed the micronutrient composition of the formulated table wine from ugiri and watermelon blends. Sample UGWM1 containing $100 \%$ ugiri had the least composition for vitamin A content with $5.019 \mathrm{mg} / 100 \mathrm{~g}$ while sample UGWM7 has the highest mean value for vitamin A with $5.539 \mathrm{mg} / 100 \mathrm{~g}$. There was no significant $(p<0.05)$ difference between all the samples for vitamin $A$ in week zero. The vitamin $C$ composition showed significant $(p<0.05)$ differences between all the samples. The vitamins $C$ ranged from $8.823 \mathrm{mg} / 100 \mathrm{~g}$ in sample UGWM6 to $21.568 \mathrm{mg} / 100 \mathrm{~g}$ in sample UGWM4 for week zero. This high vitamin $C$ level was due to the high vitamin content of both ugiri and watermelon. The results obtained were similar to $15.86 \mathrm{mg} / 100 \mathrm{~g}, 15.66 \mathrm{mg} / 100 \mathrm{~g}$ reported by Pisoschi et al. (2011) on some fruit wines and the result $10.0 \mathrm{mg} / 100 \mathrm{~g}$ and $15.0 \mathrm{mg} / 100 \mathrm{~g}$ reported by Awe et al. (2013) on pawpaw and banana wines. The calcium content of the formulated table wine blends for week zero was in the range $0.043 \mathrm{mg} / 100 \mathrm{~g}$ in sample UGWM7 to $0.14 \mathrm{mg} / 100 \mathrm{~g}$ in sample UGWM1. The result for calcium were lower than the ones $(3.88 \mathrm{mg} / 100 \mathrm{~g}$ for palm wine and 4.93 for kunu zaki) reported by Ogbonna et al. (2013) and $12.0 \mathrm{mg} / 100 \mathrm{~g}$ for pawpaw wine and 8.0 $\mathrm{mg} / 100 \mathrm{~g}$ for banana wine reported by Awe et al. (2013). There were significant $(p<0.05)$ differences in the mean values obtained for phosphorus for week zero. The phosphorus content for week zero ranged from 0.224 $\mathrm{mg} / 100 \mathrm{~g}$ in sample UGWM1 to $0.889 \mathrm{mg} / 100 \mathrm{~g}$ in sample UGWM2. The result were, however, lower than 3.59 
Table 7. Micronutrient composition of the formulated table wine blend for the four weeks storage period.

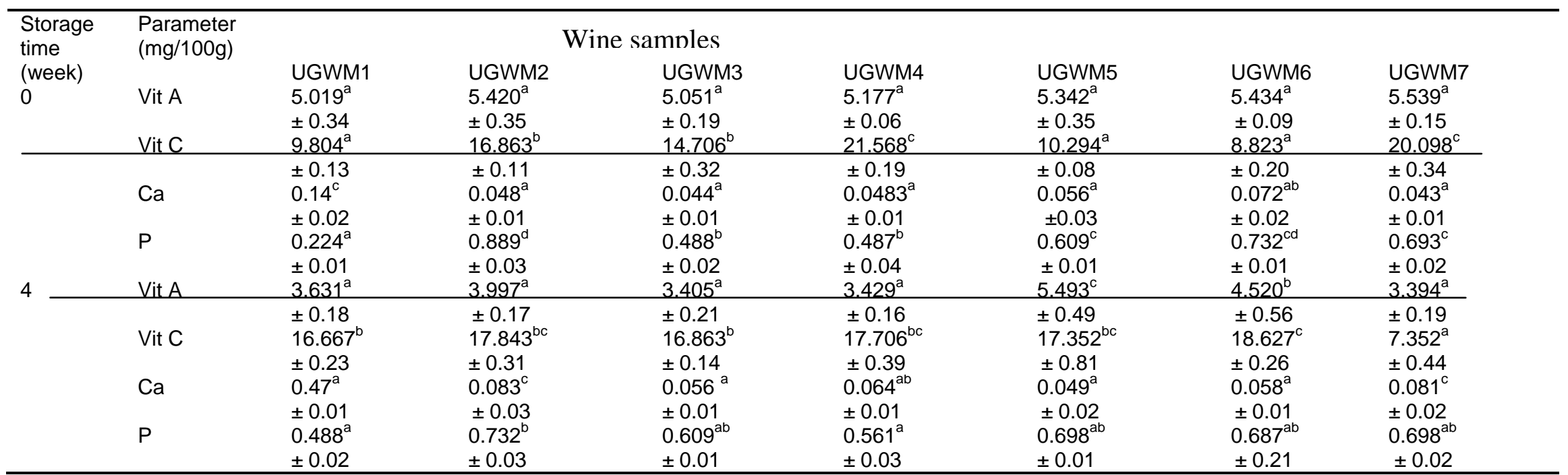

Values are in means \pm standard deviation of duplicate determination. Values with the same superscript in the same column are not significantly ( $p<0.05)$ different.

Key: UGWM1 = 100\% Ugiri; UGWM2 = 100\% Watermelon; UGWM3 = 90\% watermelon $+10 \%$ ugiri; UGWM4 = 80\% watermelon $+20 \%$ ugiri; UGWM5 = 70\% watermelon +

$30 \%$ ugiri; UGWM6 $=60 \%$ watermelon $+40 \%$ ugiri; UGWM7 $=50 \%$ watermelon $+50 \%$ ugiri. NB: UG $=$ African bush mango or ugiri; WM $=$ watermelon

$\mathrm{mg} / 100 \mathrm{~g}$ reported for fresh tomato wine and 134.5 $\mathrm{mg} / 100 \mathrm{~g}$ reported for 6 month aged tomato wine by Many et al. (2014).

However, the vitamin A content for week four showed a decrease from week zero with sample UGWM7 having $3.394 \mathrm{mg} / 100 \mathrm{~g}$ as the least mean value in week four and sample UGWM5 with $5.493 \mathrm{mg} / 100 \mathrm{~g}$ as the highest mean value. The vitamin A values were, however, lower than 24.0 $\mathrm{mg} / 100 \mathrm{~g}, 23.7 \mathrm{mg} / 100 \mathrm{~g}, 22.8 \mathrm{mg} / 100 \mathrm{~g}, 21.67$ $\mathrm{mg} / 100 \mathrm{~g}, \quad 20.5 \mathrm{mg} / 100 \mathrm{~g}$ and $20.0 \mathrm{mg} / 100 \mathrm{~g}$ reported by Adedeji and Oluwalana (2013) from watermelon and pawpaw wine. The vitamin C content for the four week ranged from 7.352 $\mathrm{mg} / 100 \mathrm{~g}$ in sample UGWM7 to $18.627 \mathrm{mg} / 100 \mathrm{~g}$ in sample UGWM6. Also, the calcium content ranged from $0.047 \mathrm{mg} / 100 \mathrm{~g}$ in sample UGWM1 and 0.081 in sample UGWM7 for week four. The phosphorus however showed some significant ( $p$ $<0.05$ ) increase when compared with week zero. The mean range for phosphorus ranged from $0.488 \mathrm{mg} / 100 \mathrm{~g}$ in sample UGWM1 to 0.732 $\mathrm{mg} / 100 \mathrm{~g}$ in sample UGWM2 which were lower than $3.59 \mathrm{mg} / 100 \mathrm{~g}$ reported for fresh tomato wine and $134.5 \mathrm{mg} / 100 \mathrm{~g}$ reported for 6 month aged tomato wine by Many et al. (2014).

\section{Microbial count (cfu/ml) of formulated table wine from ugiri and watermelon blends.}

Table 8 shows the total viable count (TVC) of the formulated table wine for weeks zero to four.

The trends observed in the four weeks storage studies for total viable count showed a great decrease from the mean values observed for week one and this may probably be due to the effect of the alcohol present in the formulated table wine on the microorganism. However, there was a remarkable increase in the total viable count for week three. However, a decrease in the total viable count was observed in week three across the table and a further decrease in week four. The results of the four weeks showed the sample would be preserved for a considerable period of time before spoilage.

Table 9 shows the mould count (cfu/ml) over the period of four week for the formulated table wine from ugiri and watermelon blends. Sample UGWM1 has no mould count for three of the four weeks, the only week being the second week with $1 \times 10 \mathrm{cfu} / \mathrm{ml}$. Samples UGWM2 and UGWM3 increased in their mould count as the weeks passed by. Samples UGWM4 and UGWM7 also exhibited an increase in mould count until the third 
Table 8. Total viable count (TVC) in cfu/ml of the formulated table wine for the four weeks storage period

\begin{tabular}{llllll}
\hline Sample & Week 0 & Week 1 & Week 2 & Week 3 & Week 4 \\
\hline UGWM1 & $2.6 \times 10^{5}$ & $1.04 \times 10^{5}$ & $1.2 \times 10^{6}$ & $1.15 \times 10^{5}$ & $4.2 \times 10^{4}$ \\
UGWM2 & $2.0 \times 10^{5}$ & $1.46 \times 10^{5}$ & $1.2 \times 10^{6}$ & $5.6 \times 10^{4}$ & $4.1 \times 10^{4}$ \\
UGWM3 & $7.6 \times 10^{5}$ & $1.8 \times 10^{5}$ & $2.0 \times 10^{6}$ & $6.8 \times 10^{4}$ & $4.1 \times 10^{4}$ \\
UGWM4 & $5.0 \times 10^{5}$ & $1.21 \times 10^{5}$ & $2.4 \times 10^{6}$ & $1.06 \times 10^{5}$ & $3.1 \times 10^{4}$ \\
UGWM5 & $8.9 \times 10^{5}$ & $2.01 \times 10^{5}$ & $1.4 \times 10^{6}$ & $3.9 \times 10^{4}$ & $3.7 \times 10^{4}$ \\
UGWM6 & $4.3 \times 10^{4}$ & $4.6 \times 10^{4}$ & $1.9 \times 10^{6}$ & $7.2 \times 10^{4}$ & $4.7 \times 10^{4}$ \\
UGWM7 & $1.0 \times 10^{5}$ & $2.81 \times 10^{5}$ & $2.6 \times 10^{6}$ & $3.2 \times 10^{4}$ & $4.8 \times 10^{4}$ \\
\hline
\end{tabular}

Values are means of duplicate determinations. Key: UGWM1 = 100\% Ugiri; UGWM2 = 100\% Watermelon; UGWM3 = 90\% watermelon $+10 \%$ ugiri; UGWM4 $=80 \%$ watermelon $+20 \%$ ugiri; UGWM5 $=70 \%$ watermelon $+30 \%$ ugiri; UGWM6 $=60 \%$ watermelon $+40 \%$ ugiri; UGWM7 $=50 \%$ watermelon $+50 \%$ ugiri. NB: UG $=$ African bush mango or ugiri; $\mathrm{WM}=$ watermelon

Table 9. Mould count in cfu/ml of the formulated table wine

\begin{tabular}{llllll}
\hline Sample & Week 0 & Week 1 & Week 2 & Week 3 & Week 4 \\
\hline UGWM1 & - & - & $1 \times 10$ & - & - \\
UGWM2 & $2.0 \times 10$ & $3.0 \times 10$ & $4 \times 10$ & $4.5 \times 10$ & $5.0 \times 10$ \\
UGWM3 & $1.0 \times 10$ & $5.0 \times 10$ & $6.0 \times 10$ & $6.5 \times 10$ & $7.0 \times 10$ \\
UGWM4 & $4.0 \times 10$ & $7.0 \times 10$ & $7.0 \times 10$ & $6.0 \times 10$ & $6.0 \times 10$ \\
UGWM5 & - & - & $1.0 \times 10$ & $2.0 \times 10$ & - \\
UGWM6 & $1.0 \times 10$ & - & $2.0 \times 10$ & - & $1.0 \times 10$ \\
UGWM7 & $5.0 \times 10$ & $8.0 \times 10$ & $9.0 \times 10$ & $8.0 \times 10$ & $7.0 \times 10$ \\
\hline
\end{tabular}

Values are in mean of duplicate determination. Key: UGWM1 $=100 \%$ Ugiri; UGWM2 $=100 \%$ Watermelon; UGWM3 $=90 \%$ watermelon $+10 \%$ ugiri; UGWM4 $=80 \%$ watermelon $+20 \%$ ugiri; UGWM $5=70 \%$ watermelon $+30 \%$ ugiri; UGWM6 $=60 \%$ watermelon $+40 \%$ ugiri; UGWM7 $=50 \%$ watermelon $+50 \%$ ugiri. NB: UG $=$ African bush mango or ugiri; WM = watermelon, - No growth

Table 10. Sensory scores of formulated table wine from ugiri and watermelon blends in week zero

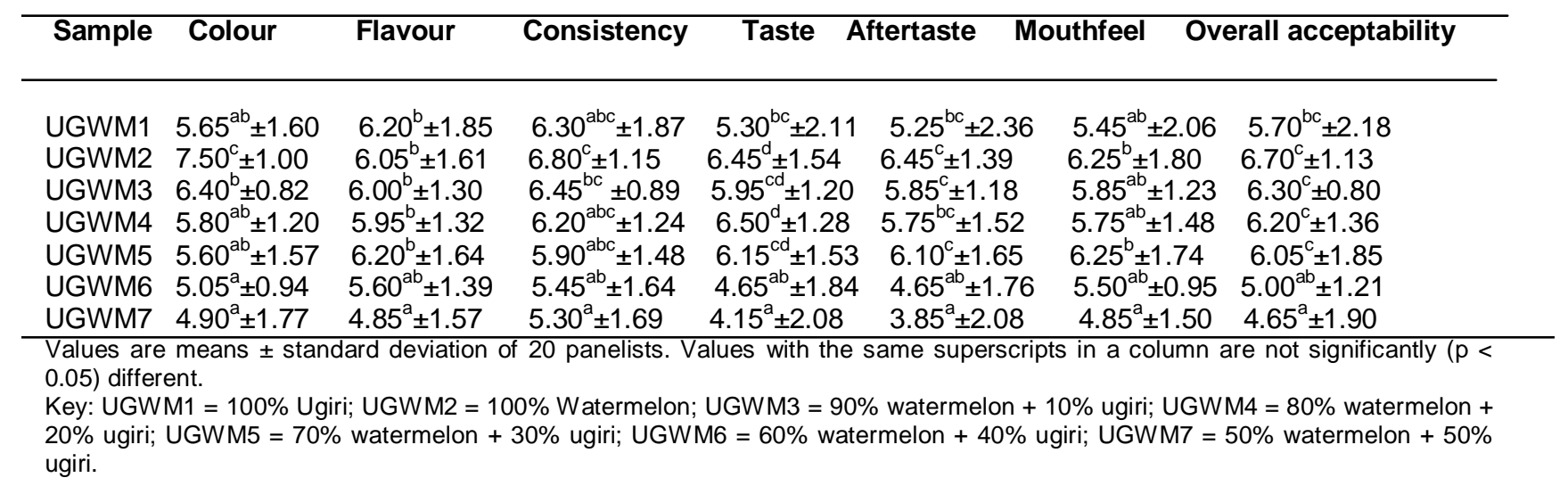

week but with noticeable decrease in the fourth and final week of storage. Sample UGWM6, however, showed the presence of mould in weeks zero, two and four. The results obtained were however contrary to the Standard Organization of Nigeria (SON) limit of zero mould tolerance in wine. 
Mbaeyi et al. 025

Table 11. Sensory scores of formulated table wine from ugiri and watermelon blends after week four

\begin{tabular}{cccccccc}
\hline Sample & \multicolumn{1}{c}{ Colour } & Flavour & \multicolumn{2}{c}{ Consistency } & Taste & Aftertaste Mouthfeel & $\begin{array}{c}\text { Overall } \\
\text { acceptability }\end{array}$ \\
\hline UGWM1 & $5.95^{\mathrm{ab}} \pm 1.40$ & $6.10^{\mathrm{ab}} \pm 1.74$ & $6.10^{\mathrm{abc}} \pm 1.76$ & $5.40^{\mathrm{b}} \pm 2.09$ & $5.20^{\mathrm{a}} \pm 1.99$ & $5.25^{\mathrm{a}} \pm 1.86$ & $5.75^{\mathrm{ab}} \pm 1.89$ \\
UGWM2 & $7.30^{\mathrm{c}} \pm 1.30$ & $6.05^{\mathrm{ab}} \pm 1.54$ & $6.80^{\mathrm{c}} \pm 1.15$ & $6.35^{\mathrm{c}} \pm 1.42$ & $6.45^{\mathrm{b}} \pm 1.15$ & $6.45^{\mathrm{b}} \pm 1.67$ & $6.60^{\mathrm{b}} \pm 1.14$ \\
UGWM3 & $6.35^{\mathrm{b}} \pm 0.81$ & $6.10^{\mathrm{ab}} \pm 1.29$ & $6.30^{\mathrm{bc}} \pm 1.17$ & $5.80^{\mathrm{bc}} \pm 1.20$ & $5.40^{\mathrm{ab}} \pm 1.31$ & $5.85^{\mathrm{ab}} \pm 1.23$ & $6.05^{\mathrm{b}} \pm 0.89$ \\
UGWM4 & $6.20^{\mathrm{ab}} \pm 1.36$ & $6.15^{\mathrm{ab}} \pm 1.18$ & $6.10^{\mathrm{abc}} \pm 1.12$ & $6.40^{\mathrm{c}} \pm 1.60$ & $5.60^{\mathrm{ab}} \pm 1.53$ & $5.90^{\mathrm{ab}} \pm 1.71$ & $6.15^{\mathrm{b}} \pm 1.18$ \\
UGWM5 & $5.85^{\mathrm{ab}} \pm 1.63$ & $6.30^{\mathrm{b}} \pm 1.53$ & $5.80^{\mathrm{abc}} \pm 1.44$ & $5.90^{\mathrm{bc}} \pm 1.48$ & $6.35^{\mathrm{b}} \pm 1.60$ & $6.20^{\mathrm{ab}} \pm 1.40$ & $6.00^{\mathrm{b}} \pm 1.95$ \\
UGWM6 & $5.50^{\mathrm{ab}} \pm 1.15$ & $5.50^{\mathrm{ab}} \pm 1.32$ & $5.15^{\mathrm{a}} \pm 1.63$ & $4.90^{\mathrm{ab}} \pm 1.92$ & $4.55^{\mathrm{a}} \pm 1.61$ & $5.25^{\mathrm{a}} \pm 1.25$ & $4.95^{\mathrm{a}} \pm 1.10$ \\
UGWM7 & $5.30^{\mathrm{a}} \pm 1.59$ & $5.20^{\mathrm{a}} \pm 1.54$ & $5.40^{\mathrm{ab}} \pm 1.67$ & $4.60^{\mathrm{a}} \pm 1.93$ & $4.70^{\mathrm{a}} \pm 1.89$ & $5.20^{\mathrm{a}} \pm 1.40$ & $5.05^{\mathrm{a}} \pm 1.61$ \\
\hline
\end{tabular}

Values are means \pm standard deviation of 20 panelists. Values with the same superscripts within a column are not significantly different $(p<0.05)$.

Key: UGWM1 = 100\% Ugiri; UGWM2 = 100\% Watermelon; UGWM3 = 90\% watermelon + 10\% ugiri; UGWM4 $=80 \%$ watermelon + $20 \%$ ugiri; UGWM5 $=70 \%$ watermelon $+30 \%$ ugiri; UGWM6 $=60 \%$ watermelon $+40 \%$ ugiri; UGWM7 $=50 \%$ watermelon $+50 \%$ ugiri

\section{Sensory scores of formulated table wine from African bush mango and watermelon blends}

Tables 10 and 11 show the sensory scores of the formulated table wine from African bush mango and watermelon blends. The mean score of colour for Week zero from Table 10 ranged from 4.90 in sample UGWM7 ( $50 \%$ watermelon $+50 \%$ African bush mango) to 7.50 in sample UGWM2 (100\% watermelon). This was probably due to the red colour of watermelon. Similar results were observed for Week four from Table 11 where the mean score ranged from 5.30 in sample UGWM7 (50 \% watermelon $+50 \%$ African bush mango) to 7.30 UGWM2 (100\% Watermelon). Also, in both week zero and four, sample UGWM2 (100 \% watermelon) was significant ( $p<$ 0.05) difference from samples UGWM3, UGWM1 and UGWM5 respectively.

The mean score of flavour for Week zero range from 4.85 in sample UGWM7 to 6.20 in samples UGWM1 and UGWM5 while the mean score for Week four range between 5.20 in sample UGWM5 to 6.30 in sample UGWM1. Samples UGWM1 and UGWM5 were significantly $(p<0.05)$ difference followed by 6.05 in sample UGWM2 and 6.00 in sample UGWM3 for week zero. Sample UGWM5 has the highest significant difference $(p<0.05)$ in week four, followed by sample UGWM4 with 6.15 and samples UGWM1 and UGWM4 with 6.1 , respectively.

The mean score for taste for week zero range from 4.15 in sample UGWM7 to 6.5 in sample UGWM4. Samples UGWM2 with 6.45 and UGWM4 with 6.5 had the highest score while sample UGWM7 had the lowest score. However, there was no significant $(p<0.05)$ difference between the mean values of taste obtained for all samples in week four.

As for consistency, the mean score ranged from 5.3 in sample UGWM7 to 6.8 in sample UGWM2 for the zero week with sample UGWM2 having the highest significant $(p<0.05)$ difference while there was no significant $(p<$ $0.05)$ difference between the remaining samples. The same trend was observed for the fourth week. Sample UGWM7 has the lowest mean score for aftertaste in week one with sample UGWM2. The same trend was observed in week four.

The mean score for mouthfeel was found to have no significant $(p<0.05)$ difference between week zero and week four. Whereas the overall acceptability of the formulated table wine was found to be significantly different in week zero with samples UGWM2, UGWM3, UGWM4 and UGWM5 having the highest scores but week four showed no significant $(p<0.05)$ difference as it pertains overall acceptability.

\section{CONCLUSION}

From the study, it was observed that the formulated table wine from African bush mango and watermelon blends were well rated in terms of overall acceptability of colour, flavor, taste, aftertaste, consistency and mouthfeel. The alcohol content of the formulated table wine blends were also within the range of table wine classification (between 7 and $14 \%$ ) and serve to inhibit microbial proliferation. The study also showed that products made from these under-utilized fruits can protect themselves from microbial proliferation due to the alcohol presence which falls within acceptable table wine limit. The result of the proximate composition for the period of storage studies showed that the formulated table wine is nutritious and can serve as a taste quenching beverage. The red colour of watermelon has also been shown by literature to be of health benefit when consumed. The proximate result also showed that there was no further breakdown of the soluble solids of the formulated table wine as storage days increased. The results of the four weeks storage studies showed that the samples would be stored for a 
considerable long period of time without spoilage.

It is however recommended that further studies should be carried out on formulating table wine from ugiri and grape, watermelon and grape to see if an acceptable wine would be produced. Further studies should also be carried out on the prospect of extracting flavour from ugiri because it has a beautiful smell and food colour from watermelon. It therefore showed that it can serve as a full substitute for grape fruit if little adjustment is carried out on aftertaste and colour and can also be blended with grape as a way of further enhancing the utilization of these fruits. Also, further studies should be carried out on the total soluble solid of the formulated table wine from ugiri and watermelon as well as an adjustment to $\mathrm{pH}$ and titratable acidity to meet standard requirements. It is also recommended that communities with ugiri trees/plantation should be enlightened about other uses of the fruits. Furthermore, the pectin content of fruits for substituent work should be analysed so as to determine the methanol content of the generated alcohol of the wine produce. Also, genetically modified watermelon with less seeds should be developed. A stabilizer should be use to prevent syneresis though a centrifuge should be tried out in the clarification of the wine. A cushion harvesting of ugiri that prevents it from dropping directly to the ground is hereby proposed so as to prevent bruises and wound of this climacteric fruit and reduce microbial proliferation and insect infestation.

\section{REFERENCES}

Adedeji T Oluwalana, IB (2013). Physico-chemical, sensory and microbial analysis of wine produced from watermelon (Citrullus lanatus) and pawpaw (Carica papaya) blend. Food Sci Qual Manag19: $41-51$.

Ajayi IA Ajibade O Oderinde RA (2011). Preliminary phytochemical analysis of some plant seeds. Res J Chem Sci 1(3): 58 - 62.

Akubor PI (1996). The suitability of African bush mango juice for wine production. Plant Foods Hum Nutri 49(3): 213 - 219.

Anon (2015a). USDA watermelon. USDA Agricultural Marketing Service. Available online at http://www.ams.usda.gov/standards. Accessed on $3^{\text {rd }}$ March, 2015.

Anon (2015b). Titratable acidity. Midwest Grape and Wine Industry Institute, lowa State University Extension and Outreach, Ames, lowa. pp $1-4$.

AOAC (2010). Official method of Analysis of Association of Official Analytical Chemical International $18^{\text {th }}$ ed., Published by AOAC international Gaithersburg, Maryland, USA.

Awe $S$ (2011). Production and microbiology of pawpaw (Carica papaya L) Wine. Curr Res J Biol Sci 3(5): 443 - 447.
Awe S Eniola KIT Kayode-Ishola TM (2013). Proximate and mineral composition of locally produced pawpaw and banana wine. Amer J Res Comm 1(12): 388 - 398.

Collins JK Wu G Perkins-Veazie P Spears K Claypool PL Baker RA Clevidence BA (2007). Watermelon consumption increases plasma arginine concentrations in adults. Nutri 23(3): 261 - 266.

European commission (EC). (2006). Wine: common market organization. Directorate-general for agriculture and rural development, Brussels. pp. $14-35$.

Idise OE (2011). Studies on wine production from coconut (Cocos nucifera). J Brew Distill 2(5): 69 - 74.

Ifie I Olurin TO Aina JO (2012). Production and quality attributes of vegetable wine from Hibiscus sabdariffa Linn. Afri J Food Sci 6(7): $212-215$

Iwe, M.O. (2002). Handbook of Sensory Methods and Analysis. Rojoint Communication Services Ltd., Enugu, Nigeria.

Kirk RS Sawyer R (1991). Pearson's Chemical composition and Analysis of Foods, $8^{\text {th }}$ Ed., Longman Group Ltd. London. pp. $24-$ 28, $42-48$.

Many JN Radhika, B Ganesan T (2014). Nutrient analysis of tomato wine. Intl J Innov Sci Eng Technol 1(8): 278 - 283.

McCarthy M (2013). Measurement of TA and pH. Department of Primary Industries, South Australian Research and Development Institute, Victoria. pp $1-19$.

Ogbonna CA Abuajah CI Akpan MF Udofia US (2013). A comparative study of the nutritional values of palm wine and kunu zaki. Annals Food Sci Technol 14(1): 39 - 43

Ogunsina BS Bhatnagar AS Indira TN Radha C (2012). The proximate composition of african bush mango kernels (Irvingia gabonensis) and characteristics of its oil. Ife J Sci 14 (1): $177-183$.

Pisoschi AM Pop A Negulescu GP Pisoschi A (2011). Determination of ascorbic acid content of some fruit juices and wine by voltammetry performed Pt and carbon paste electrodes. Mol 16: 1349 - 1365.

Prescott LM. Harley JP Klein OA (2005). Microbial nutrition, types of media, In: Microbiology, $6^{\text {th }}$ Ed, McGraw Hill Publishers, New York. pp. $95-105$.

Steel RGD Torrie JH (1980). Principles and procedures of statisticians, $2^{\text {nd }}$ Ed. McGraw Hill publishers, New York. pp 176 - 183.

Teniola OD Aroyeun OD Asagbra AE Banjo OO Lasaki TO Olasupo NA (2012). Production of table wine from processed tea bags using different strains of Saccharomyces cerevisiae. Nig Food J, 30(2): 44 -50 .

US Environmental Protection Agency; USEPA (1995). Technology transfer network clearing house for inventories and emission factors. Available online at www.epa.gov/ttnchiel/ap42/ch09/. Accessed on $3^{\text {rd }}$ March, 2015.

Vandermark T (2011). The Health Benefits of Watermelon Seeds. Available online at http://www.livestrong.com/article/24243healthbenefits-watermelon-seeds/. Accessed on $3^{\text {rd }}$ March, 2015.

Wang C García-Fernández D Mas A Esteve-Zarzoso (2015) .Fungal diversity in grape must and wine fermentation assessed by massive sequencing, quantitative $\mathrm{PCR}$ and DGGE. Frontirtd Microbioli PMC4615962 